\title{
EUROPAR BATASUNAREN LEGEGINTZA SISTEMA ${ }^{1}$
}

\section{THE LEGISLATIVE SYSTEM OF THE EUROPEAN UNION}

\author{
Asier García Lupiola
}

Universidad del País Vasco / Euskal Herriko Unibertsitatea

Cómo citar / Nola aipatu: García Lupiola, A. (2021). Europar Batasunaren legegintza sistema. Legebiltzarreko Aldizkaria - LEGAL - Revista del Parlamento Vasco, 2: 64-89

https://doi.org/10.47984/legal.2021.003

\section{LABURPENA}

Gaur egun Europar Batasunean dagoen legegintza-sistema Lisboako Tratatuaren bidez zehaztu zen. Nahiz eta erakunde-egituran nobedadeak izan ziren, egia esan, legegintza-funtzioen banaketari dagokionez aurretik zegoen antolaketari eutsi egin zitzaion; hala ere, are garrantzitsuagoa bilakatu zen Europako Parlamentuaren rola. Horren arrazoi nagusia elkarrekin erabakitzeko prozeduraren orokortzea izan zen. Legegintza-prozedura arrunta izena hartu zuen horrek aukera ematen dio boto unibertsal bidez eta europarrek zuzenean aukeratutako erakundeari dagokion eginkizuna betetzeko; alegia, legegintza-boterea gauzatzeko, baina Kontseiluarekin partekatuta. Aldi berean, gainerako araudi-tresnetan Europako Parlamentuaren funtzioak areagotu ziren, hain zuzen ere legegintza-prozedura berezietan eta aurrekontu-prozeduran. Testu honek gaur egun Europar Batasunaren legegintza-sistema eratzen duten berezitasun horiek guztiak aztertzen ditu.

\section{GAKO-HITZAK}

Europar Batasuna, sistema legegilea, legegintza-eskumenak, prozedura legegilea, Europako Parlamentua.

\section{ABSTRACT}

The current legal system in the European Union was defined by the Lisbon Treaty. Although there were developments in the institutional structure, the pre-existing organization was maintained regarding the distribution of legislative functions, although the relevance of the role played by the European Parliament was increased. This is mainly due to the generalization of the codecision procedure, now officially called the ordinary legislative procedure, which enables the institution elected by universal and direct suffrage by European citizens to exercise the mission that corresponds to it, that is, the exercise of the legislative power, although shared with the Council. At the same time, the functions of

1 Artikulu hau gaztelaniaz ere eskuragarri dago https://doi.org/10.47984/legal.2021.003 
the European Parliament were increased in the other normative tools, such as the special legislative procedures and the budgetary procedure. This text analyses all those particularities that make up the legislative system of the European Union today.

\section{KEYWORDS}

European Union, legislative system, legislative power, legislative procedure, European Parliament.

\section{RESUMEN}

El sistema legislativo existente en la actualidad en la Unión Europea quedó definido con el Tratado de Lisboa. Aunque hubo novedades en la estructura institucional, lo cierto es que se mantuvo la organización preexistente en lo que al reparto de las funciones legislativas se refiere, si bien se aumentó la relevancia del papel que juega el Parlamento Europeo. Ello se debe principalmente a la generalización del procedimiento de codecisión, ahora oficialmente denominado procedimiento legislativo ordinario, el cual posibilita que la institución elegida por sufragio universal y directo por la ciudadanía europea ejerza la misión que le corresponde en cuanto tal, es decir, el ejercicio del poder legislativo, aunque de manera compartida con el Consejo. Al mismo tiempo, se aumentaron las funciones del Parlamento Europeo en las demás herramientas normativas, como son los procedimientos legislativos especiales y el procedimiento presupuestario. El presente texto analiza todas esas particularidades que conforman el sistema legislativo de la Unión Europea en la actualidad.

\section{PALABRAS CLAVE}

Unión Europea, sistema legislativo, competencias legislativas, procedimiento legislativo, Parlamento Europeo.

\section{AURKIBIDEA}

I. SARRERA.

II. ERAKUNDE-EGITURA.

III. LEGEGINTZA-FUNTZIOEN BANAKETA.

IV. LEGEGINTZA-PROZEDURA ARRUNTA.

V. LEGEGINTZA-PROZEDURA BEREZIAK.

VI. VI. AURREKONTU-PROZEDURA.

VII. ONDORIOAK. BIBLIOGRAFIA. 


\section{SARRERA}

Lan honen helburua Europar Batasunaren (EB) legegintza-sistemaren azterketa orokorra egitea da. Haren bidez, Europako erakundeek Europako zuzenbide eratorria eratzen duten legeak hartzen dituzte, Europako sorrerako zuzenbidea eratzen duten tratatuen ondoren kokatzen diren legeak. Bi ordenamendu horiek osatzen dute EBren sistema juridikoaren gailurra, eta ordenamendu nazionalen gainean nagusitzen dira. Europako legegintza-sistemak, gaur egun, EBren Tratatuan (EBT) eta EBren Funtzionamenduari buruzko Tratatuan (EBFT) jasotzen den araudia jarraitzen du, 2009ko abenduaren lean indarrean sartu zen Lisboako Tratatuaren bitartez eginiko erreformaren ondoren ezarrita geratu bezala².

Europako integrazio-prozesuaren garapenerako ezaugarrietako bat haren legegintza-sistemaren etengabeko erreforma izan da, zeina haren erakunde-antolamenduaren egitura eta funtzionamenduaren etengabeko bilakaerarekin paraleloan egin baita. Horrela, Europako Parlamentua, europar hiritarrak ordezkatzen dituen erakundea, gero eta eskumen gehiago bereganatzen joan da eta, hala, parlamentu nazionalek betetzen duten eginkizunera gero eta gehiago hurbildu da.

Goian aipatutako helburua betetzeko, testu honek EBren legeak egiteko prozesua haren erakunde-egituraren testuinguruan kokatzen du. Jarraian, legegintza-boterearen banaketa azaltzen du, erakunde bakoitzaren funtzioak argi gera daitezen. Ondoren, EBren lege-ekoizpenaren pieza nagusiaren azterketan jartzen du arreta, alegia, legegintza-prozedura arruntean, izenak adierazi bezala, gaur egun gehien erabilitako arautze-tresnan. Hori alde batera utzita, dauden beste arau-prozedurak aztertzen dira; alde batetik, prozedura bereziak, eta, bestetik, aurrekontu-prozedura. Horrek guztiak aukera ematen du legegintza-prozesuan parte hartzen duen erakunde bakoitzak betetzen duen eginkizuna egoki hautemateko eta dagoeneko bi ganberako sistematzat jotzen den ereduaren osoko ikuspegia izateko. Azkenik, egindako azterlanaren ondorioak jasotzen dira.

\section{ERAKUNDE-EGITURA}

Lisboako Tratatuak honako erronka honi egin behar izan zion aurre: oso antzekoak ziren sei estatu kiderentzat sortutako erakunde-egitura bost aldiz kide gehiago zituen erakunde-egiturara moldatzea. Horrela, Tratatuak zenbait nobedade ekarri zituen, eta haien helburua honako hau izan da: erakundeen eta EBren erabakitzeko mekanismoen eraginkortasuna sendotzea, haren ekintza demokratizatzea eta eskumenak areagotzea (Duch i Guillot, 2009: 54), bai eta barne demokrazia handiagoa ematea

2 Jarraitzen dugun testu juridikoa da Versiones consolidadas del Tratado de la Unión Europea y del Tratado de Funcionamiento de la Unión Europea (Europar Batasunaren Aldizkari Ofiziala, C 202, 2016ko ekainak 7). Lan honetan kontuan hartu da ere Eusko Jaurlaritzak egin dituen itzulpenak Herri Arduralaritzaren Euskal Erakundearen Itzultzaile Zerbitzu Ofizialaren bidez (www.euskadi.eus/eusko-jaurlaritza/contenidos/ informacion/tr_lisboa/eu_tr_lisbo/tr_lisbo.html). 
erabakiak hartzeko mekanismoetan eta gardentasuna handiagoa lan egiteko moduan (Martín y Pérez de Nanclares, 2010: 35).

Emaitza ikusita, egiaztatu behar da Lisboako Tratatuak sartu zituen aldaketek sendotu egin dutela legezkotasun demokratikoa; izan ere, Europako Parlamentuaren legegintza-funtzioak sendotu dira eta erakunde horrek Batzordeko lehendakaria hautatzen du. Aldaketa horiek, halaber, eraginkortasuna hobetzen dute, eta horretan Kontseiluaren lehendakaritzen berrantolaketak eta Batzordearen tamainaren murrizketak ere laguntzen dute ${ }^{3}$. Hala ere, erreforman beste faktore batzuek ere izan zuten eragina, besteak beste: tentsio politiko handiak eta estatu kideek EBren gobernuan presentzia izatea sendotzeko interes nagusia (Andrés, 2008: 220); horri Kontseilu Europarraren erakundetzearekin erantzun zitzaion.

Erakunde-egitura aurkeztu aurretik, printzipio demokratikoei buruzko xedapenen artean, EBTk honako hau ezartzen du (10. artikulua): EBren funtzionamendua ordezkaritzazko demokrazian oinarritzen da; beraz, batetik, herritarrak zuzenean egongo dira Europako Parlamentuak ordezkatuta, eta, bestetik, estatu kideen ordezkaria Kontseilu Europarrean haien estatuburua edo gobernuburua izango da, eta Kontseiluan, haien gobernuak. Nolanahi ere, erakunde-antolamendua handiagoa da; izan ere, Batzordea, Justizia Auzitegia, Europako Banku Zentrala eta Kontu Auzitegia ere barne hartzen ditu. Erakunde-esparruaren helburuak EBren balioak sustatzea, helburuak betetzea, haren interesak, herritarrenak eta estatu kideenak defendatzea eta haren politika eta ekintzen koherentzia, eraginkortasuna eta jarraitutasuna bermatzea dira (EBTaren 13. artikulua).

Azken biak (Europako Banku Zentrala eta Kontu Auzitegia) eduki ekonomikoko erakundeak dira eta EBFTan arautzen dira esklusiboki. Beste bostak, erakunde nagusitzat jo beharrekoak, EBTaren III. tituluan (Instituzioei buruzko xedapenak) ezarritako araudiaren xede dira, zeina EBFTaren seigarren zatiko I. tituluan jasotakoarekin (instituzioei buruzko xedapenak) osatzen baita ${ }^{4}$. Haien artean, bi talde bereizi behar dira, ordezkatzen eta defendatzen dituzten funtzioen arabera. Batetik, nazioz gaindiko erakundeak, EBren interesak defendatzeko diseinatuak: Europako Parlamentua, Batzordea eta Justizia Auzitegia. Bestetik, gobernuen arteko erakundeak, non interes nazionalen defentsak zehazten baitu haien dinamika: Kontseilu Europarra eta Kontseilua.

Europako interesen eta interes nazionalen kontrajartze-egoera horrek agerian uzten du zein konplexua den EBren erakundeen funtzionamendua, erakundeek maila nazionalean duten funtzionamendua baino konplexuagoa, berez hori ere nahiko kon-

3 Horren harira, honako hau egiazta daiteke: erakunde-egitura berriak eta erabakiak hartzeko egitura berriak aukera ematen dute herritarrek hobeto ulertzeko Europar Batasunak zer egiten duen eta nork, nola eta zergatik hartzen dituen gu guztiongan eragina duten erabakiak (Duch i Guillot, 2009: 62).

4 Ikusten denez, erakunde-arauketa oso zatikatuta dago, eta horren motiboa honako hau da: kontu konplexuenen azpian dauden akordio politikoek eragindako teknika da, baina araugintza-teknika gisa erdipurdikoa dena (Andrés, 2008: 205). 
plexua dela kontuan hartuta. Horrek, aldi berean, honako hau azaltzen du: zaila da argi eramatea botereen ohiko bereizketa -betearazlea, legegintzakoa eta judiziala- EBren eremura, non elkarren arteko inguruek askoz ere muga gutxiago baitituzte (Muñoz de Bustillo y Bonete, 2009: 80). Ikusten denez, EBren erakunde-antolaketa oso konplexua da, non maila anitzeko testuinguru batean -europarra, nazionala eta estatu-azpikoaEB beraren eta estatu kideen interesen arteko tentsioa nabaria baita, eta erakundeen arteko lankidetza- edota norgehiagoka-dinamikak gertatzen baitiren (Elías, 2015: 73).

Europako erakundeen arteko funtzio-banaketa ez dator bat estatuen egungo sistema politikoetan indarrean dagoen Montesquieu eskemarekin. Haietan, Parlamentuak legegintza-boterea du; Gobernuak, betearazlea, eta Justizia Administrazioak, botere judiziala. EBn, legegintza-funtzioa Europako Parlamentuaren eta Kontseiluaren artean banatzen da; botere betearazlea Kontseiluaren esku geratzen da, Kontseilu Europarraren partaidetza handiarekin, bai eta Batzordearena ere, eguneroko gobernuari dagokionez. Justizia Administrazioa Justizia Auzitegiaren esku geratzen da. Egitura horretan, bi ganberako parlamentuz hitz egiten da eta betearazle bikoitzaz. Lehenengoari buruz aurrerago hitz egingo dugu eta, betearazlea dela-eta, gobernuen artekoa (Kontseilu Europarra eta Kontseilua) eta Europakoa (Batzordea) bereizi behar ditugu (Mangas, 2015: 34).

EBTak 13. artikuluan egiten duen erakundeak zerrendatzeko hurrenkera ez da kasuala; lehentasun-hurrenkera ezartzen da haien artean eta, hala, lehenengo lekuan europar herritarrengandik zuzenean datorrena dago. Hala, bada, Europako Parlamentuari EBko herritarren ordezkaritza dagokio (EBTaren 14.2 artikulua), eta boto unibertsalez eta zuzenean hautatzen da bost urteko agintaldirako (EBTaren 14.3 artikulua). 1979tik, bost urtean behin egiten da nazio anitzeko zuzeneko demokraziako ariketa hori; hala, Europako Parlamentua EBn zuzeneko legezkotasun demokratikoa duen erakunde bakarra da (Pérez de las Heras, 2010: 17). Erakunde hori gaur egun zazpiehun eta bost diputatuk eratzen dute, eta legegintzako funtzioa eta aurrekontu-funtzioa betetzen ditu, biak Kontseiluarekin batera, bai eta kontrol politikoko funtzioa eta kontsultakoa ere (EBTaren 14.1 artikulua). Kontrol-funtzioak direla-eta, Europako Parlamentuak Batzordearen lehendakariaren eta kideen hautaketa onesten du (EBTaren 17.7 artikulua), zentsura-mozioa onar dezake eta batzordekideen dimisio kolektiboa eragin (EBTaren 17.8 artikulua). Batzordearen gain ez ezik, Kontseiluaren gain ere baditu kontrol-mekanismoak, hain zuzen, parlamentarismoan ohikoak direnak, hala nola, galderak, agerraldiak, txostenak eta ikerketa-taldeak (López, 2018: 668). Ikusten denez, egungo Europako Parlamentuak baditu, dagoeneko, parlamentu nazionalen berezko eskumenak (Peñalver, 2016: 160)

Lisboako Tratatuak Kontseilu Europarra erakundetzen du, eta EBren egitura organikoan sartzen $\mathrm{du}$; hori hala da, erakunde horrek gero eta garrantzi handiagoa duelako eta estatu handiek erakunde-sistemaren gobernuen arteko ezaugarriak sendotu nahi dituztelako (García-Chamón, 2009: 98). Orain, beraz, bi erakundetan daude presen- 
te, dagoeneko, estatuen interesak ${ }^{5}$. Baina, nahiz eta Europako Parlamentuaren atzean egon -horrek garrantzi sinbolikoa baduela kontuan hartuta-, Kontseilu Europarraren garrantzia agerikoa da; izan ere, EBren garapena bultzatzea dagokio, baita haren norabide eta lehentasun politikoak zehaztea ere (EBTaren 15.1 artikulua). Hau da, aurretik bazeuzkan zuzendaritza, orientazio eta sustapen politikoaren funtzioak barneratu egiten dira erakunde-sisteman eta, hori horrela, Kontseilu Europarraren gorentasun politikoaren aintzatespenaren kasuan gaude (Andrés, 2010: 60). Are gehiago, zuzendaritza politiko eta juridikoko organo gisa gailentzen da, ohiko erakunde-orekak aldatzeko ahalmenarekin (Elías, 2015: 85). Erakunde hori estatu kideetako gobernuburuek edo estatuburuek eratzen dute, bai eta haren lehendakariak eta Batzordeko lehendakariak ere (EBTaren 15.2 artikulua), eta sei hilean bi aldiz batu behar dira (EBTaren 15.3 artikulua). Kontseilu Europarreko lehendakaria erakundeak berak hautatzen du, bi urte eta erdiko agintaldirako, zeina behin berrizta baitaiteke.

Esan bezala, Europako Parlamentuarekin batera, legegintzako funtzioa eta aurrekontu-funtzioa betetzeko erakunde arduraduna Kontseilua da; hari Europako politikak zehaztea eta koordinatzea ere badagokio (EBTaren 16.1 artikulua). Kontseilua estatu kide bakoitzeko ordezkari batek osatzen du, ministerio mailakoak (EBTaren 16.2 artikulua) $^{6}$. Zenbait osaeratan batzen da, Gai Orokorren Kontseilua da haien guztien lanen koherentzia bermatzeko arduraduna eta Atzerri Arazoetako Kontseilua EBren kanpo-ekintza prestatzekoa. Gainerako osaeren kopuruaren zehaztapena Kontseilu Europarrak erabakitzen du (EBTaren 16.6 artikulua) ${ }^{7}$. Gaur egun, Kontseiluak erabaki bat hartu behar duen gehienetan, gehiengo kualifikatuaren bidez hartzen du. Hura lortzeko, EBren biztanleriaren \% 65 ordezkatzen duten estatu kideen \% 55en (15 estatu kide) aldeko botoa behar da (EBTaren 16.4 artikulua) ${ }^{8}$.

Europako Parlamentuak herritarren interesak eta Kontseiluak estatu kideen interesak ordezkatzen dituzten bitartean, Batzordeak EBren interes orokorra sustatzen du. Hori horrela, Tratatuak eta erakundeek hartutako arauak aplikatzen direla bermatzen du -horregatik ezagutzen da tratatuen zaindari legez-, aurrekontua betearazten du eta EBren programak kudeatzen ditu (EBTaren 17.1 artikulua). Era berean, Batzordeari

5 Europako Kontseilua erakunde gisa aitortzeak berez estatuak erakunde barruan sendotzea dakar (Mangas, 2007: 135). Aldaketa horrek, beste batzuen artean, egiaztatu egiten du gobernuen arteko euskarri nabarmena, nahiz eta erakunde sistemaren demokratizazio eta eraginkortasun handiena (gehiengo kualifikatuaren bidez erabakitzeko eta Europako Parlamentuarekin elkarrekin erabakitzeko gai gehiago) EBn oreka eta dinamika berrietarako aukera emango duen kontrapuntua den (Mangas, 2008: 227). Hala ere, batzuek ulertzen dute Lisboako Tratatuak honako hau egin zuela: herritarrengandik datorren eta Europako Parlamentuaren bidez eta Europar Kontseiluan eta Kontseiluan ordezkaritza duten estatu kideen bidez zuzenean adierazitako legitimitate demokratiko bikoitza argitzea (Ordóñez, 2009: 120).

6 Badago aukera estatu bat gobernu zentralak ahaldundutako lurralde-erakunde bateko gobernu bateko kideak ordezkatzeko (hori Alemaniaren kasuan gertatu da eta behin baino gehiagotan herrialde horrek Kontseiluan Land bateko ministro baten bidez parte hartu du).

7 Kontseiluaren osaeren zehaztapena Europako Kontseiluaren esku uzten da, horretarako beharrik egon gabe; izan ere, Lisboako Tratatua baino lehen funtzio hori beti bete izan du Kontseiluak berak (Andrés, 2008: 210).

8 Kontseilua Batzordearen aurretiko proposamenik gabe aritzen bada, gehiengo kualifikatua lortzeko EBren biztanleriaren \% 65 ordezkatzen duten estatu kideen \% 72 ren (20 estatu kide) aldeko botoa behar da. 
EBren legegintza-egintzak hartzeko beharrezkoak diren proposamenak egitea dagokio (EBTaren 17.2 artikulua). Gaur egun, 27 batzordekidek -estatu kide bakoitzeko nazional bat- eratzen dute; independenteki dihardute eta haien artean daude Batzordearen lehendakaria eta Batasuneko atzerri-politika erkideko goi-ordezkaria (EBTaren 17.4 artikulua). Horiek guztiak beren eskumen orokorragatik eta Europarekiko konpromisoagatik hautatzen dira estatu kideen akordio bidez, eta Europako Parlamentuaren onarpen botoa jaso behar dute.

EBko Justizia Auzitegiak barne hartzen ditu Justizia Auzitegia, Auzitegi Orokorra eta auzitegi espezializatuak (lehen instantzian zenbait gai ezagutuko dituzte). Haren funtzioa da tratatuen interpretazioan eta aplikazioan zuzenbidearekiko errespetua bermatzea (EBTaren 19.1 artikulua), alegia, EBren egintzen legezkotasuna kontrolatzea eta estatu kideek Europako zuzenbidea betetzen dutela eta egoki interpretatzen dutela kontrolatzea. Justizia Auzitegia estatu kide bakoitzeko epaile batek eratzen du, eta hamaika abokatu orokorren laguntza du; Auzitegi Orokorrak epaile bat izango du, gutxienez, estatu kide bakoitzeko (EBTaren 19.2 artikulua).

Erakunde ekonomikoak Europako Banku Zentrala eta Kontu Auzitegia dira. Europako Banku Zentralak EBren diru-politika zuzentzen du, euroguneko estatu kideen banku zentralekin batera (EBFTaren 282. artikulua). Kontuen Auzitegia estatu kide bakoitzeko nazional batek osatzen du, eta EBren kontuen kontrolaz arduratzen da (EBFTaren 285. artikulua).

III. LEGEGINTZAFUNTZIOEN BANAKETA
Aurretik aipatu dugu EBren zazpi erakundeen artean bost nagusiz hitz egin daitekeela. Bada, EBren antolaketa-arkitekturan, sistemaren euskarriaren bilaketan sakondu daiteke. Nukleo hori erakunde-triangelu izenekoa da, eta Europako Parlamentuak, Kontseiluak eta Batzordeak eratzen dute. Hiru erakundeen arteko lankidetza EBren konstituzionaltasun demokratikoaren funtsezko oinarri gisa uler daiteke (Bondandy et al., 2004: 52). Zehazki, hiru horien artean banatzen da Europako legegintza-boterea; hala ere, egia da Batzordeak zeregin mugatua baino ez duela, baina oso garrantzitsua, eta Europako Parlamentua eta Kontseilua direla legeak egiten dituztenak.

Hori ez da beti hala izan, zehazki Europako Parlamentuari dagokionez, eta hala nabaritzen da Europako zuzenbide eratorria prestatzeko egon diren tresnen bilakaeran. Hala, Europako Erkidegoetako eratze-tratatuetan aurreikusitako erakunde-sistemak Kontseiluaren esku utzi zituen legegintzako funtzioak eta betearazleak, eta Europako Parlamentuaren eginkizuna (orduan Biltzarra) oso mugatua zen; izan ere, kontsultarako baino ez zen funtzioa betetzen zuen, eta Kontseilua ez zen politikoki arduraduna Europako Parlamentuaren aurrean. Hortik aurrera, EBren erakunde-historia Kontseiluaren botereen mugaren historia da; muga hori EBren gainerako erakundeen eginkizuna sen- 
dotzearen bidez gertatzen da, baina, bereziki, Europako Parlamentuarena sendotzearen bidez (Gil-Robles, 2007: 27). Horrela egin du tratatu berri bakoitzak eta Europako Parlamentua parlamentu normal bat izatera hurbildu dute, nahiz eta oraindik ezaugarri batzuk falta diren, adibidez, legegintzako ekimena (Brack \& Costa, 2018: 3). Zehazki, elkarrekin erabakitzeko prozedura sartzeak eta zabaltzeak Europako legeriaren legezkotasun demokratikoaren sendotze ukaezina ekarri du, EBren funtzionamendua ordezkaritzazko demokrazian oinarritzen delako baieztapenarekin koherentea dena (Garzón, 2015: 66).

Europako Erkidegoetan, oro har erabilitako arau-prozedura -1986ra arte- kontsulta-prozedura izan zen, aholku-irizpen izenez ezagutzen dena. Hark bereizgarri du eginkizunak banatzen direla Batzordearen eta Kontseiluaren artean; labur esanda, Batzordeak proposatu egiten du eta Kontseiluak, erabaki. Kontseiluak erabakia hartu aurretik, eta arautzen denaren arabera, Europako Parlamentuari kontsulta egin behar zaio, eta nahitaezko irizpen izenez ezagutzen dena eman behar du. Kontsulta nahitaezkoa ez denean, Kontseiluak erabakitzen du kontsulta egin ala ez Europako Parlamentuari; beraz, erakunde horrek aukerako irizpena ematen du, eskatzen zaionean.

1970eko hamarkadaren erdialdean, Europako Parlamentuaren kontrol-botereak areagotu egin ziren Erkidegoaren aurrekontuaren gainean; erabaki-botere erreala ere hartu zuen bere gain, derrigorrezko gastuei dagokienez. Nobedade horrek desadostasun nabarmena eragin zuen aurrekontu-botereen eta Europako Parlamentuaren arau-botereen artean. Egoera horren ondorioz, erakunde horrek Kontseiluarekin eta Batzordearekin prozedura erabakitzaile berria sortzea adostu zuen, kontzertazio-prozedura, zeinak Kontseiluaren eta Europako Parlamentuaren akordioa eskatzen baitzuen, finantza-inplikazio handiak zituzten irismen orokorreko egintzen gainean erabaki bat hartzeko. Baina praktikan gutxitan jo zen hartara.

Europako arau-sistemaren lehen erreforma handia 1986an egin zen, Europako Agiri Bakuna (EAB) iritsi zenean; hark, nahitaezko irizpenaren aplikazio-eremua handitzeaz gainera, bi prozedura berri sartu zituen. Lehena, lankidetza-prozedura. Irakurraldi bikoitzeko prozedura zen; hartan, Europako Parlamentuaren parte-hartzea sendotu egin zen, Kontseiluak onartutako testu baten gaineko zuzenketak aurkezteko aukera eman baitzitzaion. Zuzenketa horiek Batzordearen babesa izanez gero, Kontseiluak ahobatezkotasuna behar zuen haiei uko egin ahal izateko. Haren aplikazio-eremua nahiko zabala zen, barne-merkatuari buruzko hainbat gai hartzen baitzituen.

EABk sartu zuen beste arau-prozedura bat aldeko irizpena izan zen. Prozedura hori nahitaezko kontsultaren berdintsua da, baina Europako Parlamentuaren irizpenak aldekoa izan behar du Kontseiluak dagokion erabakia har dezan; beraz, nahiz eta Europako Parlamentuak ezin duen zuzenketarik sartu, badu beto-eskubidea. Erkidegoari estatu berriak atxikitzeko ezarri zen, eta elkartzeko akordioetarako eta antzekoetarako (ekonomikoak eta merkataritzakoak).

Maastrichteko Tratatuak, 1992koak, aldaketa garrantzitsuak ekarri zituen EBren arau-prozesuan. Eremu horretako erreforma nagusia elkarrekin erabakitzeko prozedu- 
ra sartzea izan zen; lankidetza-prozedura oinarritzat hartuta, Europako Parlamentuari botere erabakitzaile handiagoa ematen zion, eta erakunde-triangeluaren funtsezko elementu gisa kokatzen zuen, Kontseiluarekin eta Batzordearekin batera (Louis, 2003: 34). Nobedade horrek aldaketak ekarri zituen aurretik zeuden prozeduretan, nagusiki kontzertazio- eta lankidetza-prozeduretan. Bi horien aplikazio-eremuaren zati handi bat elkarrekin erabakitzeko prozedura berrira igaro zen. Horrek, praktikan, kontzertazioa alde batera uztea ekarri zuen eta lankidetzari eutsi egin zitzaion, aurretik kontsulta-prozeduran zeuden gaiak hartu zirelako. Azken hori dela-eta, haren aplikazio-eremua ere areagotu egin zen, eta kasu asko aukerako kontsultatik nahitaezko kontsultara igaro ziren. Azkenik, aldeko irizpenaren prozeduraren aplikazio-eremua nabarmen zabaldu zen.

Nahiz eta prozedura berririk ez sartu, Amsterdameko Tratatuak, 1997koak, aldaketa esanguratsuak ekarri zituen aurretik zeuden prozeduretan. Zalantzarik gabe, erreformarik handiena elkarrekin erabakitzearena izan zen; izan ere, aldaketak izan zituen bai egituran, sinplifikatu egin baitzen, bai haren aplikazio-eremuan, zabaldu egin baitzen. Zabalkuntza hori lankidetza-prozeduraren kontura egin zen, zeina oro har desagertu egin baitzen eta Ekonomia eta Diru Batasunaren inguruko kasuetarako baino ez baitzen mantendu. Halaber, kontsulta-prozeduraren mende zeuden gaiak elkarrekin erabakitzeko prozedurara igaro ziren, baina egia da prozedura horri EBren eskumen berrien inguruko gaiak esleitu zitzaizkiola. Aldeko irizpena bere horretan geratu zen; izan ere, hasieran haren aplikazio-eremuan sartzea pentsatu ziren gaiak azkenean elkarrekin erabakitzeko prozeduran sartu ziren.

Nizako Tratatuak 2001ean eginiko erreformak nobedade gutxi ekarri zituen legegintza-eremuan. Eginiko aldaketen artean, azpimarratzekoa da zenbait prozedura erabakitzaileren aplikazio-eremuak zabaldu izana, eta kontsultaren eta elkarrekin erabakitzearen ingurukoa nabarmentzen da, eta ez hainbeste aldeko irizpenarena. Alderdi negatiboa dela-eta, lankidetza-prozedura mantentzen dela aipatu behar dugu, eta are gehiago negoziazioetan hura desagertzea defendatzen zela kontuan hartzen badugu.

Lisboako Tratatuak, 2007koak, orain arteko azken erreformak ezarri zituen eta, hala, gaur egun indarrean dagoen EBren arau-sistemaren diseinua zehaztu zuen. Nabarmentzekoa da erabat sinplifikatu zuela sistema, elkarrekin erabakitzeko prozedura legegintzako prozedura arrunt gisa orokortu baitzuen. Azken urratsa da elkarrekin erabakitzeko prozeduraren bilakaeran, zeinak Europako Parlamentua oro har legegilekide bilakatu baitu eta, beraz, Europako legeriaren erantzunkide juridiko eta politiko (Garzón, 2015: 59). Prozedura horrek EBren erabakiak hartzeko prozesuaren supranazionalizazioa ekarri du (Berthu, 2004: 25) eta aukera ematen du EB erakunde federal gisa bereizten duten elementutzat hartzeko, beste elementu batzuen artean (Molina del Pozo, 2016: 38).

Gainera, legegintzako prozedurak erabiltzeko eskumena zer erakundek duten argitzen du, eta ez du inolako zalantzarik uzten. Aurreko epigrafean ikusi dugunez, gaur egun EBTk zehatz-mehatz zehazten du arautzeko gaitasuna Europako Parlamentuari 
eta Kontseiluari dagokiela, eta argi eta garbi zehazten du bi alditan: Europako Parlamentuak Kontseiluarekin batera beteko ditu legegintzako funtzioa eta aurrekontuko funtzioa (EBTaren 14.1 artikulua) eta Kontseiluak Europako Parlamentuarekin batera beteko ditu legegintzako funtzioa eta aurrekontuko funtzioa (EBTaren 16.1 artikulua). Nabarmentzekoa da tratatuei atxikitutako protokoloen artean, subsidiariotasun- eta proportzionaltasun-printzipioen aplikazioari buruzkoan (2. protokoloa), EBko legegile izendapena erabiltzen dela, bi erakundeei erreferentzia egiteko, legegintzako funtzioan elkarrekin dihardutenean'.

Ikusten den bezala, Lisboako Tratatuak burutu egin du Europako Parlamentuak ordezkatzen duen herritarren legezkotasuna legegintzako eta aurrekontuko botereetan sartzeko aurreko erreformen joera, erabakitze-sistema demokratizatzeko etengabeko bidean (Guinea, 2007: 24) ${ }^{10}$. Aipatu da zentzu horretan aurrerapen handiena elkarrekin erabakitzeko prozeduraren orokortzeak markatzen duela, alegia, Kontseiluaren eta Europako Parlamentuaren akordiorako beharrak, EBren zuzenbide eratorriko arauak hartu ahal izateko (Navarro, 2007: 331). Elementu horrek EBn hasiberri den ganbera-bitasuna egiaztatzen du (Andrés, 2008: 223). Eta egiazta daiteke benetako ganbera biko legegintza-organoa dela, non Europako Parlamentuak herritarren ordezkari den ganberaren funtzioak betetzen baititu eta Kontseiluak Senatuaren eginkizuna betetzen baitu, estatu kideen gobernuen ordezkari gisa (Moussis, 2008: 163). Hala da, Kontseilua bigarren legegintza-ganbera gisa aritzen da, estatu konposatuen lurralde-ordezkaritza duten bigarren ganberen modura (Elías, 2015: 92). Etorkizunera begira, ganbera biko legegintza-sistema finkatu behar da, eta, hartan, Europako Parlamentua sendotu behar da eta Kontseiluak erabakiak hartzean duen pisua murriztu behar da (Molina del Pozo, 2016: 32).

Kontseilu Europarra legegintza-boterearen jardunetik baztertuta geratzen da, esplizituki; izan ere, EBT zehatza da legegintzako funtziorik beteko ez duela ezartzean (EBTaren 15.1 artikulua). Erakunde horren funtzioak kontuan hartuta, xedapen horrek EBren barruan lanaren banaketaren aitorpena ematen du, politikoa eta arauzkoa (Andrés, 2010: 59) ${ }^{11}$.

Batzordea dela-eta, erakunde horrek eginkizun garrantzitsua betetzen du; izan ere, gehienetan, legegintzako prozedura haren ekimenez hasten da, zeinak proposamen bat aurkezten baitu gero Europako Parlamentua eta Kontseilua haren gainean lanean

9 Nahiz eta Europako Parlamentua eta Kontseilua legegintza ahalaren titular izan, ez da ahaztu behar gai oso garrantzitsuetan (eskumenari buruzko arauak, ekonomikoak eta monetarioak) Kontseiluak eta Batzordeak jarraitzen dutela EBren egintzak emateko eskumena izaten, eta, nahiz eta "legegintzako egintza" izena eman ezin zaien, haien indar bera dutela (Linde, 2010: 264).

10 Europako Parlamentuaren beraren arabera, oro har erakunde hori EBren legeria erabakitzen duena izateak -Kontseiluarekin parean- hobekuntza nabarmena erakusten du herritarrek EBren jarduketaren inguruko kontrol handiagoa izateko, erantzukizun demokratikoa areagotzean. Resolución del Parlamento Europeo sobre el Tratado por el que se establece una Constitución para Europa (2004/2129(INI)), 2005eko urtarrilaren 12, 4-5.

11 Hala ere, 2008ko ekonomia- eta finantza-krisialdia hasi zenetik, Kontseilu Europarrak legerian eragina izateko ahalegina egin du. Hala egin $\mathrm{du}$, haren bileren ondorioetan Kontseiluaren jarrera xehetasunez argitaratuz, Kontseiluari berari dagokion funtzioa, eta, hala, erakunde horren negoziazio-gaitasuna murriztu da (Peñalver, 2016: 158). 
hasteko. Esan daiteke Batzordeak legegintza-agenda zehazten duela baina lege-ekoizpenaren protagonistak Europako Parlamentua eta Kontseilua direla (López, 2018: 667). EBren legegintzako egintzak Batzordeak eskatuta baino ezingo dira hartu, tratatuek besterik xedatzen duten kasuetan izan ezik (EBTaren 17.2 artikulua). Salbuespena kasu gutxiri dagokie eta, zehazki, estatu kideen edo Europako Parlamentuko talde baten ekimenez onetsi ahalko dira egintzak, Europako Banku Zentralak gomendatuta edo Justizia Auzitegiak edo Europako Inbertsio Bankuak eskatuta (EBFTaren 289.4 artikulua). Hiritar-ekimena aurreikusten bada ere, Batzordeari zuzendutakoa izan behar da, eta honek erabakiko du proposamena luzatzen dien Europako Parlamentuari eta Kontseiluari (EBTaren 11.4 artikulua) ${ }^{12}$. Gainera, ikusi denez, legegintzako egintza bat aurretik Batzordearen proposamena eginda prestatzeak dakar Kontseilua gehiengo kualifikatu eskuragarriagoz ebatzi behar izatea.

Laburki bada ere, beharrezkoa da interes-taldeei buruzko aipamena egitea. Lobbie izenez ezagutuak, EBren legeak egiteko prozeduretan edo legeen egikaritzean eragina izan nahi duten taldeak dira. 1990.eko hamarkadaren erdian Bruselan ezarrita zeuden interes-taldeak 3000 inguru zirela uste zen baina 2011n Europako Parlamentuak eta Batzordeak erregistro partekatua martxan jarri zutenetik 8000 talde baino gehiago ezagutu dira, nahiz eta oraindik gehiago direla suposatzen den erregistroaren borondatezko izaera dela eta (Oliver, 2019: 93) ${ }^{13}$. Europako erakundeen urruntasuna kritikatzen denean eta horien legitimitatea indartzeko helburuarekin, gizarte zibilaren parte-hartzea sustatzeko interes-taldeen bidezko parlamentu-formulak aztertu behar dira, beti ere talde horiek era egokian eta beharrezko berme guztiak beteta erregistratu behar direlarik (Pernas, 2019: 32).

Hori dela eta, legegintza prozesuan parte hartzen duten hiru erakundeek (Europako Parlamentuak, Kontseiluak eta Batzordeak) berriki adostu dute interes-taldeen derrigorrezko erregistroa eratzeko akordioa, gardentasun erregistroa izena hartzen duena hain zuen ere $^{14}$. Horren arabera, erakundeek legeen inguruan interesak dituzten taldeekin etengabeko elkarrizketa izatea positiboa dela onartzen dute, iritzi eta ezagutza espezializatuak gehitzeko aukera sortzen baita eta, horrela, erabakiak hartzearen kalitatea hobetzen baita. Erakundeek elkarrizketa horren gardentasuna beharrezkoa dela azpimarratzen dute, hiritarrek interes-taldeen jarduera eta eragina ezagutu ahal izateko. Hain zuzen ere, hortik eratortzen da erregistroaren derrigorrezkotasuna.

Atal honekin bukatzeko, legegintzako egintzei aipamena egingo diegu, hau da, legegintzako prozeduren bidez onetsitako egintza juridikoak (EBFTaren 289.3 artikulua).

12 Europar hiritartasuna indartzeko nabarmentzeko pausoa izan bada ere, azpimarratzen da Europako Parlamentuari baino Batzordeari zuzendutako ekimena izatea, eta, ondorioz, zeharkako hiritar-ekimena dela adierazten da (Burguera, 2016: 126).

13 2021eko abuztuaren 24ean EBren Gardentasun Erregistroak 12890 entitate jasotzen ditu. https://ec.europa.eu/transparencyregister/

14 Acuerdo interinstitucional entre el PE, el Consejo de la UE y la Comisión Europea sobre un Registro de transparencia obligatorio, 2021eko maiatzak 20 (DOUE L 207, 2021eko ekainak 11). 
Zehazki, Batzordeak proposatuta Europako Parlamentuak eta Kontseiluak legegintzako prozedura arruntaren bidez elkarrekin hartutako erregelamenduak, zuzentarauak edo erabakiak dira (EBFTaren 289.1 artikulua), edo Europako Parlamentuak Kontseiluaren parte hartzearekin edo Kontseiluak Europako Parlamentuaren parte hartzearekin hartutakoak, legegintzako prozedura bereziaren bidez. Ikusi den bezala, EBFTk zehazten du, halaber, zer erakunderi dagokion legeak egitea.

Legegintzako egintzak derrigortasunaren eta hartzaileen arabera bereizten dira (EBFTaren 288. artikulua):

- Erregelamenduak irismen orokorra izango du. Derrigorrezkoa izango da haren elementu guztietan eta zuzenean aplikatu ahalko da estatu kide bakoitzean.

- Zuzentarauak estatu kide hartzailea behartuko du, lortu behar den emaitzari dagokionez eta, hala ere, agintari nazionalei utziko die moduaren eta baliabideen hautaketa.

- Erabakia derrigorrezkoa izango da haren elementu guztietan. Hartzaileak esleitzean, haietarako baino ez da izango derrigorrezkoa.

Legegintzako egintzekin batera, EBTk eskuordetutako egintzak eta betearazpen-egintzak onesteko aukera jasotzen du; egintza horiek legez besteko egintzak dira. Eskuordetutako egintzak legez besteko egintza orokorrak dira, eta Batzordeak onesten ditu legegintzako egintza baten elementu ez funtsezko batzuk osatzeko edo aldatzeko, kontuan hartuta legegintzako egintza horrek zehazten duela eskuordetzea, berariaz, helburuei, edukiari, irismenari eta iraupenari dagokienez (EBFTaren 290. artikulua). Eskuordetutako egintzak onesteak erraztu egiten du zenbait alderdi teknikotan edo xehetasuneko alderditan erabaki eraginkorrenak hartzea (Martín y Pérez de Nanclares, 2010: 54). Betearazpen-egintzak Batzordeak onesten ditu eta, behar bezala arrazoitutako kasu zehatzetan, Kontseiluak, EBn juridikoki lotesleak diren egintzen -hala eskatzen dutenen kasuan- betearazpenerako baldintza berdinak arautzeko -estatu kideen aldetik, barneko zuzenbideko neurrien bidez- (EBFTaren 291. artikulua).

IV. LEGEGINTZAPROZEDURA ARRUNTA

Elkarrekin erabakitzeko prozedura EBFTaren 294. artikuluan arautzen da -orain legegintzako prozedura arrunt gisa-, eta xedapen hori hamabost ataletan banatzen da. Lehen biak prozeduraren hasierari dagozkio eta, hortik aurrera, arauketa-prozedurak gara ditzakeen lau faseetan multzokatzen da: lehen irakurraldia (3-6. atalak), bigarren irakurraldia (79. atalak), adiskidetzea (10-12. atalak) eta hirugarren irakurraldia (13. atala). Azkenik, epeak zabaltzeko aukera (14. atala) eta xedapen berezi batzuk jasotzen dira (15. atala).

Prozedura Batzordearen proposamen batekin hasten da; hura Europako Parlamentuari eta Kontseiluari aurkezten zaie (2. atala). Zehazki, estatu baten edo batzuen intereseko helbururik ez nagusitzeko, Batzordearen proposamen-eskubidea berme bat 
da interes orokorretarako (Mangas, 2015: 19). Hala ere, badago aukera legegintzako prozedura estatu kideen talde baten edo Europako Parlamentuaren ekimenez hasteko, Europako Banku Zentralak gomendatuta edo Justizia Auzitegiak eskatuta (15. atala); kasu horietan guztietan apurtu egiten da Batzordeak duen legegintza-ekimenaren monopolioa (Dougan, 2008: 639). Baina Batzordeak ematen dio hasiera prozedurari kasu gehienetan; horregatik esan daiteke legegintzako ekimenaren boterea jarraitzen duela Batzordeak izaten, kuasimonopolio erregimenean (Ugartemendia, 2010: 9) ${ }^{15}$.

Lehenengo irakurraldia honela hasten da: Europako Parlamentuak bere jarrera onartzen du Batzordearen proposamenaren aurrean eta hura Kontseiluari transmititzen zaio (3. atala). Kontseiluak, beraz, bi aukera ditu:

- Europako Parlamentuaren jarrera onesten badu, prozedura amaituko da, kasuan kasuko egintza jarrera horren arabera onestean (4. atala).

- Europako Parlamentuaren jarrera onesten ez badu, Kontseiluak bere jarrera onetsi eta Europako Parlamentuari jakinaraziko dio (5. atala), eta bere jarrera onesteko izan dituen arrazoi guztien berri emango dio (6. atala).

Bigarren kasu horretan, bigarren irakurraldia hasten da eta Europako Parlamentuak hiru hileko epea izango du Kontseiluaren jarrera aztertzeko. Haren amaieran, honako hiru egoera hauetakoren bat gerta daiteke (7. atala):

- Europako Parlamentuak Kontseiluaren jarrera onesten du, edo ez du erabakirik hartzen. Kasu horietan, egintza Kontseiluaren jarreraren arabera onetsi dela ulertzen da eta prozedura amaitzen da.

- Europako Parlamentuak bere kideen gehiengoz baztertzen du Kontseiluaren jarrera. Kasu horretan, ez onetsitzat joko da proposatutako egintza, eta legegintza-prozedura amaituko da.

- Europako Parlamentuak Kontseiluaren jarrerarako zuzenketak onesten ditu bere kideen gehiengoz. Aldatutako testua Kontseiluari eta Batzordeari helaraziko zaie, eta zuzenketei buruzko irizpena emango du Batzordeak.

Kontseiluak Europako Parlamentuaren zuzenketak jasotzen dituenetik hiru hileko epea du haiek aztertzeko, eta honako bi erabaki hauek hartu ahalko ditu (8. atala):

- Kontseiluak Europako Parlamentuaren zuzenketa guztiak onesten baditu -gehiengo kualifikatuz, baldin eta Batzordeak aldeko irizpena eman badu, edo, aho batez, baldin eta irizpena kontrakoa bada (9. atala)-, egintza onetsita amaituko da prozedura.

15 Tratatuei atxikitutako lehen protokoloak, EBn Parlamentu nazionalen egitekoari buruzkoak, prozedura bat ezartzen du parlamentu nazionalek subsidiariotasun-printzipioaren zaindari lanetan jardun ahal izateko, legegintza-egintzen proiektuen inguruan. Horrek Batzordearentzat esan nahi du bere legegintza-ekimenek ere parlamentu nazionalen kontrol serioa izango dutela (Mellado, 2010: 88). Estatuek EBren eskumenetan duten beste kontrol-mekanismo bat da, zeina parlamentu nazionalen esku geratzen baita eta aukera ematen baitie Europako legeriaren izapidetzea jatorrian eteteko (Linde, 2010: 258). Esan daiteke legegintza-sistemaren kontraesan demokratiko baten aurrean gaudela (Vecchio, 2011: 15). Parlamentu nazionalek EBren legegintza-prozesuan parte hartzeko aukera hori dela eta, bada ganbera biko ala hiru ganberako sistemaren aurrean gauden galdetzen duena (Cooper, 2013: 532) 
- Kontseiluak Europako Parlamentuaren zuzenketa guztiak onesten ez baditu, Kontseiluko lehendakariak, Europako Parlamentuaren lehendakariarekin bat etorriz, Adiskidetze Komitea deitu beharko du, sei asteko epean.

Bi erakunde legegileen ordezkariek Adiskidetze Komitean egin behar duten lana da adiskidetze-fasearen bereizgarria (10. atala). Kontseiluak bere kide guztiekin edo haien ordezkariekin parte hartzen du eta Europako Parlamentuak, ordezkarien kopuru berarekin. Komitearen misioa da testu bateratuaren inguruko akordioa lortzea, zeina bi erakundeen bigarren irakurraldiko jarreretan oinarritzen baita. Europako Parlamentuaren eta Kontseiluaren jarrerak hurbil daitezen sustatzeko, Batzordeak Adiskidetze Komitearen lanetan parte hartuko du (11. atala). Akordioa lortzeko, Kontseiluko kideek edo haien ordezkariek gehiengo kualifikatuz hartuko dute erabakia, eta Europako Parlamentuko ordezkariek gehiengo soila baino ez dute beharko. Lanek Adiskidetze Komitean gehienez sei aste iraungo dute.

Epe horretan Adiskidetze Komiteak testu bateraturik onesten ez badu, ez onetsitzat joko da proposatutako egintza (12. atala). Epe berean Komiteak testu bateratua onesten badu, hirugarren irakurraldia izango da (13. atala). Hartan, Europako Parlamentuak eta Kontseiluak sei asteko epea izango dute kasuan kasuko egintza onesteko testu bateratu horrekin bat etorrita. Europako Parlamentuak emandako botoen gehiengoz hartuko du bere erabakia, eta Kontseiluak, berriz, gehiengo kualifikatuz. Prozedura hirugarren irakurraldi honekin amaitzen da, nolanahi ere, dela bi erakundeek egintza onesten dutelako dela epe horretan bi erakundeetako batek onartu ezean egintza onesten ez delako.

Prozeduraren arauketa salbuespen batzuekin amaitzen da. Hala, batetik, xedapenean aurreikusten diren hiru hileko eta sei asteko aldiak luzatu egin daitezke, gehienez hilabetez eta bi astez, hurrenez hurren, Europako Parlamentuaren eta Kontseiluaren ekimenez (14. atala). Bestetik, Batzordeari buruzko zehaztapenak -2., 6. eta 9. ataletan jasotzen dira- ez dira aplikatuko prozedura estatu kideen taldeak edo Europako Parlamentuak proposatuta, Europako Banku Zentralak gomendatuta edo Justizia Auzitegiak eskatuta hasten denean. Kasu horietan, Europako Parlamentuak eta Kontseiluak Batzordeari egintzaren proiektua igorriko diote, bai eta lehenengo eta bigarren irakurraldiko jarrerak ere. Bi erakunde horiek Batzordearen irizpena eskatu ahalko dute prozeduran zehar, eta erakunde horrek bere borondatez eman ahalko du (15. atala).

Adiskidetzeak dakarren negoziazioa erakundeen arteko elkarrizketa etengabea da; hartan, legegintzako testuak inplikatuta dauden hiru erakundeetako ordezkarien artean negoziatzen dira. Denborarekin, erakundeen arteko elkarrizketa-formatu hori prozeduraren lehen bi irakurraldietara eraman da, eta, hala, akordioa eta legegintzako egintzak lehenengo irakurraldietan onestea erraztu da. Eta hori hala da, nahiz eta EBFTan horren harira ezer ez ezarri, Batzordeak kasu horretan Europako Parlamentuaren eta Kontseiluaren artean jarrerak hurbiltzeko eginkizuna betetzen duelako eta, horretarako, irtenbideak proposatzen dituelako desadostasunek prozedura gelditu dezaketenean 
(Gómez-Leal, 2015: 113). Horrek ere agerian uzten du hiru erakundeen arteko benetako elkarlana (Batzordea, Europako Parlamentua eta Kontseilua) ezinbestekoa dela arauak adostu eta tratatuen helburuak lortzeko (Mangas, 2015: 16) ${ }^{16}$. Horrela, elkarrekin erabakitzeko prozeduraren bilakaeraren bereizgarria da aplikazioaren lehen urteetan gehienak adiskidetzean oinarrituta onetsitako egintzak zirela -horrek prozedurak gehiegizko denbora behar izatea zekarren (Vecchio, 2011: 14)-, eta, denborarekin, areagotzen joan direla lehenengo irakurraldian amaitutakoak, harik eta gehiengo bilakatu arte ${ }^{17}$. Guzti horren ondorioz, erabakiak hartzeko orduan gai zehatzen azterketa sakonegiak edota kontsultarako epe luzeak alboratu dira, posible denean behintzat, erabakiak ahalik eta azkarren hartu ahal izateko, baina horrek ez du esan nahi gardentasuna galdu denik EBren erabakiak hartzeko prozeduran (Brandsma and Meijer, 2020: 15).

Elkarrekin erabakitzeko prozeduraren aplikazio-eremuari dagokionez, gaur egun EBren legegintzako egintzak onesteko prozedura orokorra da, alegia erregelamenduak, zuzentarauak eta erabakiak hartzekoa. Legegintzako prozedura hori Lisboako Tratatuak orokortu zuen, gehiengo kualifikatuz emandako botoa Kontseiluan aho batez onartu beharreko hainbat xedapenetara hedatzearekin batera, eta tratatu berriaren bidez gehitu ziren oinarri juridiko berrietan gehiengo kualifikatua aplikatzearekin batera. Hori horrela, ez zituen jasan aurreko Maastrichteko, Amsterdameko eta Nizako tratatuekin izan ziren arazoak.

Maastrichteko Tratatuak elkarrekin erabakitzeko prozedura EBren arau-sisteman sartu zuenean, haren aplikazio-eremua eratzen zuten gaiak sartzeko oinarriari buruzko irizpide argia eta finkoa falta zela nabaritu zen. Ez ziren gogoan hartu legegintza-egintzako garrantzi handiagoko edo txikiagoko datuak, sentsibilitate nazional handiagokoak ala txikiagokoak, ez eta Kontseiluan bozkatzeko moduaren paralelismoaren datuak ere. Horrela, Maastrichteko Tratatuak hamabost gai sartu zituen elkarrekin erabakitzeko prozesuaren aplikazioeremuan: barne-merkataritza, osasunaren eta kontsumitzaileen babesa, kultura- eta hezkuntza-neurriak, diploma eta kalifikazioen aitorpena eta baliokidetasuna, langileen zirkulazio askea, ikerketako esparru-programa eta Europa barneko sareak.

Hurrengo erreforma prozesuan, Batzordeak aplikazio-eremua zabaltzea proposatu zuen, egintzaren legegintza-izaeraren irizpidearen bidez, hau da, egintza zuzenean tratatuetan oinarritzea, nahitaezkoa izatea, EBren ekintzen funtsezko oinarriak arautzea eta irismen orokorra izatea. Amsterdameko Tratatuak elkarrekin erabakitze-

16 Hiru erakundeek konpromisoa hartu zuten, 2007 an, fede onez jarduteko elkarlanean prozedura osoan, haien jarrerak ahalik eta gehien hurbiltzeko eta, hala dagokionean, prozeduraren fase goiztiarrean egintza onesteko bidea libre uzteko. Declaración común del Parlamento Europeo, del Consejo y de la Comisión, de 13 de junio de 2007, sobre las modalidades prácticas del procedimiento de codecisión (artículo 241 del Tratado (E), Europar Batasunaren Aldizkari Ofiziala, C 145, 2007ko ekainak 30.

17 1999-2004 legealdian, honako hau izan zen proportzioa: lehen irakurraldian onetsitako egintzak, \% 29, eta adiskidetzean onetsitakoak, \% 22 2004-2009 legealdian, lehen irakurraldian onetsitako egintzak, \% 72 eta adiskidetzean onetsitakoak, \% 5, eta 2009-2014 legealdian, lehen irakurraldian onetsitako egintzak, \% 85 eta adiskidetzean onetsitakoak, \% 2 (Gómez-Leal, 2015: 116). 
ko prozeduraren hedapen handia ekarri zuen, eta aurretik lankidetza prozeduraren mende zeuden kasu guztiak hartu zituen -Ekonomia eta Diru Batasuna izan ezik-, bai eta kontsultaren mendeko kasu asko eta gai berriak ere. Horrela, elkarrekin erabakitzeko prozeduraren mende geratu ziren arlo berriak, hala nola garraioa, iruzurraren aurkako borroka, garapenerako lankidetza, ingurumen-politika, aduana-lankidetza, diskriminaziorik eza eta gizarte- eta enplegu-neurri batzuk. Hala ere, baztertu egin ziren zenbait politikaren alderdi batzuk, legegintzako izaera argia zutenak. Egoera hori, zati batean, Nizako Tratatuaren bidez konpondu zen; horretarako, aipatutako irizpide berari jarraitu zitzaion. Aplikazio-eremua berrogeita lau gaitara zabaldu zen, honako hauek barne: lankidetza judiziala gai zibiletan, industria-politika, Europako alderdi politikoak eta asiloari, immigrazio klandestinoari eta errefuxiatuei buruzko neurriak.

Lisboako Tratatuarekin, ez zen beharrik egon elkarrekin erabakitzeko prozeduraren aplikazio-eremuan gai berriak sartzeko irizpide berririk zehazteko. Legegintza-prozeduren kopurua behin betiko murriztuz sinplifikatzeko erabakiak elkarrekin erabakitzeko prozeduraren arrazoizko hedapen koherentea ekarri zuen. Horrela, aurreko erreforma prozesuetan hartatik kanpora utzi ziren legegintzako gaiak gaur egun oinarri juridiko gisa jasotzen dira, legegintzako prozedura arruntaren bidez arautzeko. Horrek, EBren legezkotasun demokratikoa areagotzeaz gainera, trinkotasun handiagoa ere ematen dio arau-prozedurari, eta, hala, murriztu egiten dira EBren erakundeen artean kasu bakoitzerako kontuan hartu beharreko lege-oinarrien inguruan egon litezkeen desadostasun deusezak (Dougan, 2008: 640).

Gaur egun, laurogeita bost gaitara hedatzen da elkarrekin erabakitzeko prozedura haiek legeztatzeko. Lisboako Tratatuak egin zuen aplikazio-eremuaren hedapena egiteko, lehenik eta behin, gaiak kontsulta-prozeduratik legegintzako prozedura arruntera aldatu ziren, Kontseiluak gehiengo kualifikatuz erabakitzen duen kasuei dagokienez. Merkataritzako politika erkidearen funtsezko gaiak dira (alde biko eta alde anitzeko merkataritza-akordioak); askatasuna, segurtasuna eta justizia, zehazki zigor zuzenbideari dagokionez; nekazaritza eta arrantza; Europol, Eurojust eta polizia-lankidetza; zerbitzuen liberalizazioa sektore zehatzetan; hirugarren herrialdeetako kapital-mugimenduei buruzko neurriak; barne-merkatuan distortsioak desagerrarazteko neurriak eta euroaren erabilerari buruzkoak. Bestalde, legegintzako prozedura arrunta orokortu zen, halaber, Lisboako Tratatuak sortutako oinarri juridiko berri gehienak, Kontseiluak gehiengo kualifikatuaren bidez onesteko, aldi berean elkarrekin erabakitzeko prozeduraren bidez arautu zirelako. Honako gai hauen inguruko neurriak dira: herritarren ekimena, hirugarren herrialdeetako nazionalak sartzea, delinkuentziaren prebentzioa, osasun publikoa, jabetza intelektuala, kirolak, ikerketa, politika espaziala, energia, turismoa, babes zibila, laguntza humanitarioa eta administrazio-lankidetza.

Zenbait gai legegintzako prozedura arruntaren aplikazio-eremutik kanpo geratu ziren, eta legegintzako prozedura bereziek arautu behar dituzte. Batzuk oso garrantzitsuak dira, hala nola fiskalitatea edo gizarte-politikaren alderdiak; gai horiek oso 
sentikorrak dira estatu kide batzuen kasuan. Zehazki, elkarrekin erabakitzeko prozeduraren bidez arautzen ez diren gai gehienak arautzeko Kontseiluak jarraitu behar du aho batez erabakitzen.

Beharbada elkarrekin erabakitzeko prozedura erabat eta guztiz orokortzea nahiko luketenen nahiari erantzuteko, Lisboako Tratatuak bide bat sartu zuen haren aplikazio-eremua zabaltzen jarraitzeko, zeina pasabide-klausula izenez ezagutzen baita. EBTaren 48. artikuluak tratatuen berrikuspen-prozedurak jasotzen ditu: bat arrunta eta bi sinplifikatuak. Horietako azkenak legegintzako prozedura berezietan biltzen diren gaiak legegintzako prozedura arruntean sartzeko tresna bat ezartzen du, tratatuak erreformatzeko prozesura jotzeko beharrik izan gabe. Hala, Kontseilu Europarrak aho batez hartu ahalko du legegintzako prozedura arruntaren aplikazio-eremura zer gai igarotzen diren zehaztuko duen erabakia, parlamentu nazional batek ere ezin dio aurka egin eta Europako Parlamentuak kideen gehiengoz onartuko du.

Nahiz eta, zalantzarik gabe, aurrerapauso garrantzitsua den eta legegintzako prozedura arrunta EBn legegintzako prozedura bakarra izateko bide eman dezakeen, onartu behar da Kontseiluan ahobatezkotasuna behar izateak -eta, neurri txikiagoan, parlamentu nazional guztien oposiziorik eza- xedapenaren aplikazio praktikoa zaildu lezakeela. Ezin da ahaztu, bestalde, EBFTaren 353. artikuluak lau kasu espezifikotan ${ }^{18}$ pasabide-klausularen aplikazioa baztertzen duela, edo mugaz gaindiko eragina duten familia zuzenbideko alderdiak, Europako Parlamentuari kontsulta egin ondoren -beraz, haren onarpena beharrezkoa izan gabe-, Kontseiluaren erabakiz elkarrekin erabakitzeko prozeduraren bidez onestera igaro ahalko direla (EBFTaren 81.3 artikulua).

Azkenik, datuek berresten dute elkarrekin erabakitzeko prozedura praktikan legegintza-prozedura arrunta izatera pasatu dela ${ }^{19}$. Izan ere, Lisboako Tratatua indarrean sartu zenetik testu hau idazten ari den momentura arte (2010eko urtarriletik 2021eko abuztura), EBFTan aurreikusitako legegintzako prozeduren bidez onetsitako egintzen \% 90 legegintza-prozedura arruntaren bidez prestatu dira. Epe horretan, 923 egintza onartu dira prozedura horren bidez, hau da, 80 egintza urtero batezbesteko. Elkarrekin erabakitzeko prozedura ezarri zuen Maastrichteko Tratatua indarren sartu zenetik eta Lisboako Tratatuak egin zuen arte 1162 egintza onartu ziren prozedura horren bidez, hau da, 70 egintza urtero batez beste. Nabaria da emandako gehitzea, hamarren bat baino gehiagokoa urteroko batezbestekoan.

Azpimarratzekoa da ere legegintza-prozedura honen bidez onetsitako egintza moten kopuruetan gertatu den aldaketa. Lisboako Tratatua baino lehen, elkarrekin eraba-

18 Baztertutako xedapenak ondokoak dira (laurak EBFTarenak): 311 . artikulua, berezko baliabideen zehaztapena; 312.2 artikulua, urte anitzeko finantza-esparruaren zehaztapena; 352.1 artikulua, EBaren helburuak lortzeko ekintzak (kanpo- eta segurtasun-politikakoak izan ezik), Tratatuek beharrezko ekintza-botereak aurreikusi ez dituztenean; 354. artikulua, EBren kide izatearen eskubideen etenaldia.

19 Adieraziko ditugun datuak, atal honetan bai eta hurrengoan ere, Eur-Lex atarian jasotakoak dira: Eur-Lex EBren legegintza testuen online argitalpen-zerbitzu ofiziala da https://eur-lex.europa.eu (azken kontsulta 2021eko abuztuaren 25ean) 
kitzeko prozeduren bidez onartutako egintzen gehiengoa zuzentarauek osatzen zuten, hain zuzen, \% 48,8; erregelamenduak \% 34,7 ziren eta erabakiak soilik \% 16,5. Ordea, legegintza-prozedura arrunta izenez ezagutzen denetik, horren bidez onartutako egintzen \% 70,5 erregelamenduak dira, \% 21,3 zuzentarauak eta \% 8,2 erabakiak. Beraz, erakunde legegileen artean akordioa erraztu den heinean, gero eta egintza gehiago lehenengo irakurraldian amaitzea lortu delarik, aldi berean, irismen orokorra duen egintza motara gehiago jo dute, erregelamendura hain zuzen ere; horrela, EBtik arautzen den gaiaren zuzeneko ezarpena orokortu da ere, estatu kideen aldetik zuzentarauek eskatzen duten transposizio-araurik behar ez delarik ${ }^{20}$.

Ikusten denez, elkarrekin erabakitzeko prozedurak funtzionatu egiten du, hasieran zantzu okerrak izan baziren ere; modu erabakigarrian lagundu du erakundeen arteko triangeluan harremanak aldatzen, eta defizit demokratikoaren salaketa orokorraren ordez legegintzako praxi publikoa ekarri du (Barón, 2012: 47).

V. LEGEGINTZAPROZEDURA BEREZIAK

Legegintzako funtzioaz hitz egitean esan den bezala, erregelamenduak, zuzentarauak eta erabakiak legegintzako prozedura arruntaren bidez onesten dira kasu gehienetan, edo legegintzako prozedura berezien bidez. Azken horien bidez, legegintzako egintzak Kontseiluak edo Europako Parlamentuak baino ezingo dituzte onetsi, eta ez erakunde biek batera (EBFTaren 289.2 artikulua). Gainera, nabarmendu behar da desagertu egiten dela Batzordearen parte-hartzea; izan ere, ez da ezartzen hiru prozedura berezietako bat ere haren proposamenarekin hastea. Aplikazio eremua osatzen duten oinarri juridikoak aurretik kontsultako, lankidetzako eta aldeko irizpeneko prozeduren aplikazio-eremuetan jasotzen ziren.

Kasu gutxi batzuetan izango da Europako Parlamentua bera legea egiten duena, baina aurretik Kontseiluaren onarpena behar da. Horrek esan nahi du prozedura berezien lehen modalitate honetan Parlamentuak EBren legegile gisa duen eginkizuna areagotu dela, elkarrekin erabakitzeko prozeduraren gainetik. Aplikazio-eremuak hiru oinarri ditu: Europako Parlamentuaren diputatuen estatutua, ikertzeko eskubidea baliatzeko modalitateak eta Europako Arartekoaren estatutua.

Beste kasu batzuetan, alderantzizko prozedurari jarraitzen zaio eta, hala, legegintzako egintzak onestea Kontseiluaren esku geratzen da, Europako Parlamentuaren aurretiko onarpenarekin. Ikusten denez, Lisboako Tratatuak aurreko aldeko irizpenaren prozeduraren inguruan eginiko egokitzapenaren aurrean gaude. Nabarmendu behar

20 Kontutan hartzekoa da Batzordeak duen legegintza-ekimena, egintza motaren proposamena egiten baitu ere. Proposatutako egintza horrek estatu kideek izango duten maniobra-tartea zehazten du, baita etorkizunerako ere, tarte hori mugatu denean (erregelamendua aukeratu denean) ez baita gero berriro ere zabalduko (Hurka and Steinebach, 2021: 292). 
da, nahiz eta legegintzako prozedura arruntaren bidez onesten ez diren eta, beraz, Europako Parlamentuaren ekarpenik izan ezin duten legegintzako egintzak izan, beharrezkoa dela erakunde hori egintza onartzearen alde agertzea, hura onets dadin. Haren aplikazio-eremuak sexuan, arrazan, erlijioan, desgaitasunean edo adinean oinarritzen diren bazterketen aurka borrokatzeko neurriak hartzen ditu, bai eta EBko herritarren eskubideak osatzeko xedapenak, zigor-arloko lankidetza judizialaren garapena, Europako Fiskaltzari buruzko sorrera eta neurriak, nazioarteko akordioak eta EB osorako hauteskunde-prozedura berdina ere.

Bestalde, kasu batzuk aurreko nahitaezko kontsulta-prozeduraren isla dira; izan ere, haietan legegintzako egintzaren onespena Kontseiluaren esku geratzen da, Europako Parlamentuari kontsulta egin ondoren. Nahiz eta oraindik Europako Parlamentuaren parte-hartzea kontsultara murrizten diren kasu ugari daudela pentsa daitekeen, egia esan prozedura hori erabat baztertuta geratzen da, eta oso kasu zehatzak dira, askatasunaren, segurtasunaren eta justiziaren eremuko kontu gutxi batzuetara mugatuak (Martín y Pérez de Nanclares, 2010: 44). Hirugarren legegintzako prozedura berezi horren aplikazio-eremuan honako kasu hauek sartzen dira, besteak beste: zirkulazio-askeari buruzko gizarte-segurtasuneko neurriak; ez nazionalen sufragio aktiboko eta pasiboko eskubidea; babes diplomatikoa eta kontsularra; zirkulazio askerako bide emateko dokumentazioari buruzko neurriak; polizia-lankidetzari buruzko neurriak, eta Europako Banku Zentralaren funtzioei eta Ekonomia eta Diru Batasunari buruzko neurriak.

Aurreko atalean zehaztu dugu Lisboako Tratatua indarrean sartu zenetik legegintza-prozedura arruntaren bidez egintzen \% 90 onetsi dela. Beraz, legegintza-prozedura berezietara \% 10ean jo da soilik. la hamaika urte eta erdiko epean 56 egintza onartu ditu Kontseiluak, Europako Parlamentuari kontsulta egin eta gero (guztizkoaren \% 5,5); eta beste 46, Europako Parlamentuaren onarpena jaso eta gero (guztizkoaren \% 4,5). Bi legegintza-prozedura berezietan erabakiak izan dira gehien onetsi diren egintzak. Kontsultaren kasuan, egintzen \% 39,3 erabakiak dira, \% 33,9 zuzentarauak eta \% 26,8 erregelamenduak. Ordea, Europako Parlamentuaren onarpenarekin onartutako egintzen \% 61 erabakiak dira eta \% 39 erregelamenduak, ez baita zuzentaraurik onartu prozedura berezi horren bidez.

Legegintzako prozedura bereziak alde batera utzita, Lisboako Tratatuak, oro har, legegintzako ekimenerako nolabaiteko gaitasuna sartu zuen Europako Parlamentuarentzat, baina hura zeharkakoa dela esan liteke. Hala, Europako Parlamentuaren iritziz EBren egintza bat behar duten gaietarako, diputatuen gehiengoaren bidez eskatu ahalko dio Batzordeari legegintzako proposamenak aurkezteko (EBFTaren 225. artikulua).

Azkenik, Europako Parlamentuak ekimen-eskubidea bereganatu du tratatuak berrikusteko prozeduran (EBTaren 48. artikulua). Berrikuspen-prozedura arruntaren bidez, Kontseilu Europarrari tratatuak berrikusteko proiektuak aurkeztu ahalko dizkio; proiektu horien helburu izan ahalko da EBri esleitutako eskumenak areagotzea edo gutxitzea. Bi berrikuspen-prozedura sinplifikatuen artean, lehenengoak Europa- 
ko Parlamentuak EBFTaren hirugarren zatiko xedapenak -EBren barneko politika eta ekintzei buruzkoak- berrikusteko proiektuak aurkezteko aukera jasotzen du. Bigarren berrikuspen-prozedura sinplifikatua aipatu dugu dagoeneko, eta helburu du legegintzako prozedura berezietan bildutako gaiak legegintzako prozedura arruntean sartzea.

\section{AURREKONTU- PROZEDURA}

Eratze-tratatuetan, Europako Parlamentuak aurrekontuaren onarpenean izan zuen parte-hartzea kontsultarako baino ez zen izan; izan ere, jatorrian, Europako Erkidegoen aurrekontua estatu kideen finantza-ekarpenen bidez baino ez zen finantzatzen. Aurrekontuaren gaineko kontrol demokratikoa parlamentu nazionalek egiten zuten, Erkidegoaren jarduerak finantzatzeko partidak onartzean.

Hala ere, 1970eko Luxenburgoko Tratatuak eta 1975eko Bruselakoak kontribuzio horiek Europako Erkidegoen berezko baliabideekin ordezkatu zituzten. Horrela, aurrekontu-boterearen gauzatzea Kontseiluaren eta Europako Parlamentuaren artean partekatu zen, eta Parlamentuari nahitaezkoak ez diren gastuen gaineko azken hitza izateko eskubidea eta aurrekontuari uko egiteko aukera eman zitzaion.

Aurrekontu-eremuan posizio esanguratsua izatean, tratatu eraldatzaileek eginiko erreformek legegintzako lan orokorrean Europako Parlamentua sendotzea izan zuten ardatz. Hala ere, Lisboako Tratatuak, legegintzako prozedura arrunta orokortzearen eta legegintzako prozedura bereziak ezartzearen bidez arau-sistema berria ezartzeaz gainera, erabat aldatu zuen aurrekontu-prozedura eta, hala, oreka-egoera finkatu zuen Europako Parlamentuaren eta Kontseiluaren artean, ez baitzuen ordurako nahitaezkoak diren eta nahitaezkoak ez diren gastuen artean bereizten. Bereizketa hori desagertzea garrantzitsutzat jo zen; izan ere, zuzenean dago lotuta Europako Parlamentuak aurrekontuaren osotasunerako duen eskumenaren hedapenarekin (Mellado, 2010: 100). Horrela, Europako Parlamentuak eta Kontseiluak EBren urteko aurrekontua ezarriko dute (EBFTaren 310. artikulua) eta Europako Parlamentua aurrekontuko agintekide dela egiaztatzen da, Kontseiluarekiko berdintasun osoan (Mangas, 2007: 146).

Urteko aurrekontuak urte anitzeko finantza-esparrua errespetatu behar du, zeina gutxienez bost urteko aldirako ezarrita baitago, EBren gastuen bilakaera antolatua bermatzeko bere baliabideen mugaren barruan (EBFTaren 312.1 artikulua). Finantza-esparru hori Kontseiluak ezarriko du erregelamendu baten bidez, Europako Parlamentuak onartu ondoren, eta lehenak aho batez erabakiko du eta bigarrenak, hura eratzen duten kideen gehiengoz (EBFTaren 312.2 artikulua).

Urteko aurrekontua onartzeko prozedura EBFTaren 314. artikuluan araututa dago. Hasteko, Batzordeak aurrekontu-proiektuaren proposamena aurkeztuko die Europako Parlamentuari eta Kontseiluari, beranduenez irailaren lean (xedapenaren 2. atala). Proiektu horren inguruan, Kontseiluak dagokion jarrera hartu eta Europako Parla- 
mentuari emango dio haren berri, beranduenez urriaren 1ean (3. atala). Europako Parlamentuak 42 eguneko epea du honako hiru bideetako bat aukeratzeko (4. atala):

- Europako Parlamentuak Kontseiluaren jarrera onartzen badu, aurrekontua onetsita geratuko da.

- Europako Parlamentuak erabakirik hartzen ez badu, aurrekontua onetsita geratuko da.

- Europako Parlamentuak kideen gehiengo osoz zuzenketak onartzen baditu, zuzenketak jaso dituen proiektua Kontseiluari eta Batzordeari igorriko zaie. Kontseiluak hamar eguneko epean zuzenketa guztiak onartzen baditu, aurrekontua haiekin bat etorriz onetsita geratuko da.

Nolanahi ere, Europako Parlamentuko lehendakariak, Kontseiluko lehendakariarekin bat etorriz, Adiskidetze Komitea deitu behar du, eta hura batu egingo da, Kontseiluak azkenean Parlamentuaren zuzenketak onartu ezean. Legegintzako prozedura arruntean gertatzen den bezala, Kontseiluak bere kide guztiekin edo gaien ordezkariekin parte hartzen du Komite horretan eta Europako Parlamentuak, ordezkarien kopuru berarekin. Komitearen misioa da testu bateratuaren inguruko akordioa lortzea, zeina bi erakundeen jarreretan oinarritzen baita; horretarako, hogeita bat eguneko epea du. Europako Parlamentuaren eta Kontseiluaren arteko jarreren arteko hurbilketa sustatzeko, Batzordeak Adiskidetze Komite horren lanetan ere parte hartzen du. Akordioa lortzeko, Kontseiluko kideek edo haien ordezkariek gehiengo kualifikatuz erabaki beharko dute, eta Europako Parlamentuko ordezkariek nahikoa dute gehiengo soilarekin (5. atala).

Adiskidetze Komiteak testu bateratuari buruzko akordiorik lortzen ez badu, Batzordeak aurrekontu-proiektu berria aurkeztuko du (8. atala). Komiteak testu bateratuari buruzko akordioa lortzen badu, Europako Parlamentuak eta Kontseiluak hamalau eguneko epea izango dute onartzeko. Epe horretan, honako lau egoeretako bat gerta daiteke (7. atala):

- Europako Parlamentuak eta Kontseiluak testu bateratua onartzen badute edo erabakirik onesten ez badute, edo bi erakundeetako batek onartzen badu eta besteak erabakirik hartzen ez badu, aurrekontua testu bateratuaren arabera onetsi dela ulertuko da.

- Bi erakundeek testu bateratuari uko egiten badiote edo bi erakundeetako batek uko egiten badio eta besteak erabakirik hartzen ez badu, Batzordeak beste aurrekontu-proiektu bat aurkeztuko du.

- Europako Parlamentuak testu bateratuari uko egiten badio eta Kontseiluak onartzen badu, Batzordeak beste aurrekontu-proiektu bat aurkeztuko du.

- Europako Parlamentuak testu bateratua onartzen badu eta Kontseiluak uko egiten badio, Parlamentuak hamalau eguneko epean lehen irakurraldian aurkeztutako zuzenketa guztiak edo batzuk egiazta ditzake, kideen gehiengoz eta emandako botoen hiru bostenaren bidez. Egiaztatu gabeko zuzenketa ba- 
koitzak esan nahi du aipatzen duen aurrekontu-ildoa mantendu egiten dela Adiskidetze Komitean hartutako jarrerarekin bat etorriz. Aurrekontua oinarri horren gainean onetsi dela ulertuko da.

Ikus daitekeenez, aurrekontuko legegintza-prozedura legegintzako prozedura arruntaren aldaera bat da -elkarrekin erabakitzeko prozeduraren modu laburtua (Jacqué, 2008: 462)-, eta horrek bide eman du eremu horretan Europako Parlamentuaren legegintza-boterea sendotzeko, bai eta erakunde hori aurreikusitako gastuen inguruko erabakia eman dezakeelako ere.

Aurrekontuaren betearazpenaren kontrola dela-eta, Lisboako Tratatuak eutsi egiten dio Batzordeak urtero Europako Parlamentuari eta Kontseiluari ekitaldi bakoitzeko kontuak eta EBren aktiboaren eta pasiboaren finantza-balantzea aurkezteko beharrari. Hala ere, Batzordeak eskuratutako emaitzetan oinarritzen den EBren finantzen ebaluazio-txostena ere aurkeztu behar diela gehitzen du (EBFTaren 318. artikulua). Era berean, jarraitzen du Europako Parlamentua izaten, Kontseiluak hala gomendatuta, Batzordearen kudeaketa onartzen duena aurrekontuaren betearazpenean. Zehazki, aurrekontua betearazteko fasean ere funtzio berriak eskuratzen ditu Europako Parlamentuak. Hori hala da, aurrekontua ezartzeko eta betearazteko modalitateak zehazten dituzten finantza-arauak eta finantza-eragileen erantzukizun-kontrola ezartzen dutenak legegintzako prozedura arruntaren arabera garatutako erregelamenduen bidez hartzen direlako (EBFTaren 322. artikulua).

Europako herriak ordezkatzen dituen erakunde gisa dagozkion botere legegileez hornitzeko Europako Parlamentuak aurrera daraman etengabeko borroka emankorra izaten ari da. Egia da Europako Erkidegoen jatorrian, arautze-boterea Kontseiluaren esku zegoela, hau da, estatuen eskuetan soilik. Hala ere, 1975etik aurrera, ordura arte soilik kontsultak jasotzen zituen Biltzarrak lehen legegintza-eskumenak jaso zituen, aurrekontuaren esparru garrantzitsuan lehenik eta kontzertazio-prozeduraren bitartez ondoren. Sufragio orokorrez hautatua izaten hasi ondoren Europako Parlamentuak bere legegintza-eskumenak handituta ikusi zituen, EABk ezarritako lankidetza eta aldeko irizpenaren prozeduren bidez.

Maastrichteko Tratatuak ezarritako elkarrekin erabakitzeko prozedurak aurrerapen kualitatibo nabarmena ekarri zuen Europako Parlamentuarentzat benetako legegintza-botereak lortzeko bidean, erakunde hori eta Kontseilua maila parekatuan kokatu baitzituen erabakiak hartzeko orduan. Egia da bi erakundeak ez zeudela prozeduraren fase guztietan egoera berean baina ordutik aurrera ezinezkoa egin zen Kontseilua legegintzarako erakunde bakarra zelako ideia defendatzea. Aldi berean, kritikatu egin zen prozedura berriak zuen konplexutasuna eta bere aplikazio-eremu mugatua. Hala ere, aurrerapauso garrantzitsua eman zen EBren izaera demokratikoa indartzeko, hau da, 
Europako Parlamentua estatu kide bakoitzaren parlamentuari dagozkion ahalmenak eta legezkotasun demokratikoa izateko egoerara hurbiltzeko.

Kritika horiei erantzuna eman zion Amsterdameko Tratatuak. Alde batetik, elkarrekin erabakitzeko prozedura sinplifikatu zuen, Europako Parlamentuaren eta Kontseiluaren arteko akordioa errazteko. Bestetik, bere aplikazio-eremua zabaldu zuen, bertan kokatu baitziren EBk jaso zituen eskuduntza berrien inguruan arautzeko oinarri juridiko ugari. Nabarmentzekoa da zabaltze hori beste prozeduretatik igorritako oinarri juridikoen igorpenaren bidez ere egin zela, hain zuzen, Europako Parlamentuaren parte-hartze mugatuago bat ahalbidetzen zuten prozeduretatik. Amsterdameko Tratatuak porrot egin zuen bete behar zuen helburu nagusia lortzeko orduan, ez baitzuen EBren ekialderako zabalkunderako beharrezkoa zen erreforma egituratu; ordea, aurretik finkaturik ez zegoen elkarrekin erabakitzeko prozeduraren moldaketa dela-eta, Europako Parlamentua irabazle atera zen. Nizako Tratatuak egin gabe zegoen erreforma orokorra ahalbidetu zuen eta, aurrekoan bezala, aurreikusita ez bazegoen ere, elkarrekin erabakitzeko prozeduraren aplikazio eremua handitu zuen berriro, Europako Parlamentuaren rola indartuz.

Elkarrekin erabakitzeko prozedurari esker lortzen ari den EBren legegintza-sistemaren demokratizazioa, Lisboako Tratatuarekin finkatu zen, Europako Parlamentua botere legegilearen ezinbesteko elementu gisa berretsi baitzen. Lisboako Tratatuak erakunde eta arau-eremuetan ekarritako erreformek gaur egun EBn indarrean dauden legegintza-funtzioak banatzeko sistema ezarri zuten. Egia da EBTak eta EBFTak horren inguruan jasotzen duten arauketak funtsean aurretik bazegoen erakunde-eskemari eusten diotela; halaber, agerikoa da ere Europako Parlamentuaren eginkizuna sendotu eta finkatu egiten duela, Europako legeak onesteko prozesua aldatzean, eta EBren benetako legegintza botere gisa finkatzen duela -hori bai, Kontseiluarekin batera- eta EB osoaren izaera demokratikoa sendotzen duela.

Arrazoi nagusia honako hau da: gaur egungo legegintzako sistemak aukera ematen du herritarrek aukeratutako erakunde bakarrak estatu kideetan aplikatuko diren legeak prestatzen erabat parte hartzeko, zeinak hierarkikoki ordenamendu nazionalen beraien gainetik baitaude eta zuzenean partikularretan eragin baitezakete. Hori, nagusiki, elkarrekin erabakitzeko prozeduraren bidez gertatzen da, zeina Lisboako Tratatuak legegintzako prozedura arrunt izendatu baitzuen. Horrela, EBn legegintzako egintzak onesteko bide arruntak dakar Europako Parlamentuak, praktikan, EBren lege gehienak prestatzen esku hartzen duela, Kontseiluaren parean. Ikusi denez, horrela gertatu da azken hamaika urteetan, EBn onartu diren hamar legeetatik bederatzi elkarrekin erabakitzeko prozeduraren bitartez onetsi baitira.

Kasu gutxitan egiten dira legeak elkarrekin erabakitzeko prozeduraz bestelako mekanismoen bidez eta, kasu horietan, Europako Parlamentuaren parte-hartzea bermatzen da, neurri handiagoan ala txikiagoan, dela onarpenaren bidez dela kontsultaren bidez, legegintzako prozedura berezietan gertatzen den bezala. Azkenik, aurrekon- 
tu-prozedura Lisboako Tratatuak erreformatu zuen eta, horretarako, elkarrekin erabakitzeko prozeduraren antzeko mekanismoa ezarri zuen, non Europako Parlamentuak aurrekontuaren osotasunaren inguruan erabakitzen hasi baitzen.

Etorkizunera begira, beharbada zaila izango da nobedade esanguratsuak egotea erakunde mailan. Agian, legegintzako organoa ganbera bikoa dela egiaztatuko da eta, hala, Kontseilua lurraldeko legegintza-ganbera gisa geratuko da, herritarren ordezkaritzako ganberarekin batera, alegia, Europako Parlamentuarekin batera. Kontseiluaren betearazpen-funtzioak Kontseilu Europarraren eta Batzordearen artean banatuta gera litezke. Ez da hain zentzugabea pentsatzea hurrengo erreforma-prozesuetan legegintzako prozedura arruntak haren aplikazio-eremua areagotzen jarraituko duela. Hori gerta liteke orain prozedura berezien mende jartzen diren gaiak legegintzako prozedura arruntaren mende jarriko direlako edo estatu kideek EBri lagatako subiranotasuna duten eskumen berriak elkarrekin erabakitzeko prozeduraren bidez legeztatuko direlako. $\uparrow$

\section{BIBLIOGRAFIA}

Andrés Sáenz de Santamaría, P. (2008). El sistema institucional en el Tratado de Lisboa: entre la continuidad y el cambio. J. Martín y Pérez de Nanclares (Koord.). El Tratado de Lisboa. La salida de la crisis constitucional (205-225 orr.). Madrid: lustel.

Andrés Sáenz de Santamaría, P. (2010). El Tratado de Lisboa y la alargada sombra de los Estados. Revista de Derecho de la Unión Europea, 18, 55-73. Hemendik eskuratua http://revistas.uned.es/index php/REDUE/article/view/12561

Barón Crespo, E. (2012). El desarrollo de la codecisión como procedimiento legislativo de la UE. Cuadernos Europeos de Deusto, 46, 19-47. Hemendik eskuratua https://doi.org/10.18543/ ced-46-2012pp19-47

Berthu, G. (2004). L'Europe sans les peuples. L'essentiel sur le projet de constitution européenne. Paris: François-Xavier de Guibert.
Bondandy, A. V., Bast, J. eta Arndt, F. (2004). Tipología de los actos en el Derecho de la Unión Europea. Análisis empírico y estructuras dogmáticas en una presunta jungla. Revista de Estudios Políticos, 123, 9-70. Hemendik eskuratua https://recyt.fecyt. es/index.php/ReuEsPol/article/view/46050

Brack, N. \& Costa. O. (2018). The European Parliament at a crossroads. The Journal of Legislative Studies, 24 (1), 1-10. https://doi.org/10.1080/135 72334.2018 .1444622

Brandsma, G. J. and Meijer, A. (2020). Transparency and the efficiency of multi-actor decision-making processes: an empirical analysis of 244 decisions in the European Union. International Review of Administrative Sciences, 0 (0), 1-18. https://doi.org/10.1177/0020852320936750

Burguera Ameave, L. (2016). Centralidad parlamentaria e iniciativa ciudadana en el proceso legislativo. Revista de Estudios Políticos, 171, 105-136. https://doi.org/10.18042/cepc/rep.171.04 
Cooper, I. (2013). Bicameral or Tricameral? National Parliaments and Representative Democracy in the European Union. Journal of European Integration, 35 (5), 531-546. https://doi.org/10.1080/07 036337.2013 .799939

Dougan, M. (2008). The Treaty of Lisbon 2007: winning minds, not hearts. Common Market Law Review, 45 (3), 617-703.

Duch i Guillot, J. (2009). El Tratado de Lisboa y los cambios en la organización institucional de la UE. Cuadernos europeos de Deusto, 40, 51-62.

Elías Méndez, C. (2015). Las instituciones europeas ante la crisis económica: análisis y propuestas para politizar y democratizar el proceso de toma de decisiones a nivel europeo. Revista de Derecho Constitucional Europeo, 24, 73-102. Hemendik eskuratua http://www.ugr.es/ redce/REDCE24/ articulos/02_ELIAS.htm

Europar Batasuna (2021). EUR-Lex. El acceso al Derecho de la Unión Europea. Hemendik eskuratua https://eur-lex.europa.eu

García-Chamón Cervera, E. (2009). Lo que se saluó del naufragio de la Constitución Europea. Del Tratado constitucional de Roma de 2004 al Tratado de Lisboa en 2007. Noticias de la Unión Europea, 291, 91-104.

Garzón Clariana, G. (2015). El Parlamento Europeo y la evolución del poder legislativo y del sistema normativo de la Unión Europea. Revista de Derecho Comunitario Europeo, 50, 43-83. Hemendik eskuratua https://recyt.fecyt.es/index.php/RDCE/ article/view/38969

Gil-Robles y Gil-Delgado, J. M. (2007). Tratado de Lisboa: un paso adelante en la evolución del sistema institucional europeo. Revista de las Cortes Generales, 70-72, 9-38. https://doi.org/10.33426/
Gómez-Leal Pérez, M. (2015). El procedimiento legislativo ordinario en la práctica: los acuerdos en primera lectura. Cuadernos Europeos de Deusto, 52, 101-118. Hemendik eskuratua https://doi. org/10.18543/ced-52-2015pp101-118

Guinea Llorente, M. (2007). La reforma institucional en el Tratado de Lisboa: entre la continuidad y el cambio. Tiempo de Paz, 87, 22-30.

Hurka, S. and Steinebach, Y. (2021). Legal Instrument Choice in the European Union. Journal of Common Market Studies, 59 (2), 278-296.

https://doi.org/10.1111/jcms.13068

Jacqué, J. P. (2008). Le traite de Lisbonne. Revue trimestrielle de droit européen, 3, 439-483.

Linde Paniagua, E. (2010). Algunas observaciones sobre el sistema normativo de la Unión Europea. Revista de Derecho de la Unión Europea, 18, 255 269. Hemendik eskuratua http://revistas.uned.es/ index.php/REDUE/article/view/12569

López Garrido, D. (2018). El Poder Legislativo de la Unión Europea. D. López Garrido (Zuz.). Lecciones de derecho constitucional de España y de la Unión Europea I (667-678 orr.). Valencia: Tirant lo Blanch.

Louis, J. V. (2003). ¿Qué instituciones para la Europa ampliada? Federación de Cajas de Ahorro Vasco-Navarra (Ed.). La ampliación europea: desafíos y oportunidades (29-38 orr.). Vitoria-Gasteiz: Federación de Cajas de Ahorro Vasco-Navarra.

Mangas Martín, A. (2007). La reforma institucional en el Tratado de Reforma. Revista de las Cortes Generales, 70-72, 127-154.

https://doi.org/10.33426/rcg/2007/70-72/684

Mangas Martín, A. (2008). El escoramiento intergubernamental de la Unión. J. Martín y Pérez de Nanclares (Koord.). El Tratado de Lisboa. La salida de la crisis constitucional (227-239 orr.). Madrid: lustel. 
Mangas Martín, A. (2015). El nuevo equilibrio institucional en tiempos de excepción. Revista de Derecho Comunitario Europeo, 50, 13-42. Hemendik eskuratua https://recyt.fecyt.es/index.php/ RDCE/article/view/38968

Martín y Pérez de Nanclares, J. (2010). La entrada en vigor del Tratado de Lisboa: un nuevo marco jurídico estable para el desarrollo de la Unión Europea. J. Martín y Pérez de Nanclares eta M. Urrea Corres. Tratado de Lisboa. Textos consolidados del Tratado de la Unión Europea y del Tratado de Funcionamiento de la Unión Europea (17-68 orr.). Madrid: Marcial Pons eta Real Instituto Elcano.

Mellado Prado, P. (2010). La reforma institucional en el Tratado de Lisboa: "Cambiar algo para que nada cambie". Revista de Derecho de la Unión Europea, 18, 75-101. Hemendik eskuratua http://revistas.uned.es/index.php/REDUE/article/ view/12562/11763

Molina del Pozo, C. (2016). El largo camino recorrido desde la descentralización hasta el federalismo: el caso de la Unión Europea. Revista de la Secretaría del Tribunal Permanente de Revisión, 8, 19-40.

https://doi.org/10.16890/rstpr.a4.n8.p19

Moussis, N. (2008). Le Traité de Lisbonne: une Constitution sans en avoir le titre. Revue du Marché commun et de l'Union européenne, 516, 161-168.

Muñoz de Bustillo, R. eta Bonete, R. (2009). Introducción a la Unión Europea: un análisis desde la economía. Madrid: Alianza Editorial.

Nauarro González, A. (2007). El Tratado para la Reforma de la Unión Europea. Revista española de Derecho Europeo, 23, 329-335. Hemendik eskuratua http://www. revistasmarcialpons.es/revistaespanoladerechoeuropeo/article/view/369
Oliver González, A. B. (2019). Análisis y Regulación del lobby en la Unión Europea. Vivat Academia. Revista de Comunicación, 149, 91-108.

https://doi.org/10.15178/va.2019.149.91-108

Ordóñez Solís, D. (2009). Lo que se saluó en Lisboa y su significado en la pequeña historia constitucional de la Unión Europea. Cuadernos Europeos de Deusto, 40, 109-148.

Peñaluer García, N. (2016). Dentro de la fábrica de salchichas: actores y proceso de toma de decisiones en el Parlamento Europeo. Cuadernos Europeos de Deusto, 55, 145-163. https://doi. org/10.18543/ced-55-2016pp145-163

Pérez de las Heras, B. (2010). De la democracia representativa a la democracia participativa: aportaciones del Tratado de Lisboa. Revista de Derecho de la Unión Europea, 18, 13-27. Hemendik eskuratua http://revistas. uned.es/index.php/REDUE/ article/view/12559

Pernas Alonso, J. M. (2019). La participación de los grupos de interés en las instituciones de la Unión Europea: propuesta específica para la elaboración de directivas y reglamentos. Revista de Estudios Europeos, 74, 30-55. Hemendik eskuratua: https://bit.ly/2Z79AcQ

Ugartemendia Eceizabarrena, J. I. (2010). La iniciativa normativa en el procedimiento legislativo europeo a la luz del Tratado de Lisboa. InDret Revista para el análisis del Derecho, 3, 1-27. Hemendik eskuratua https://indret.com/la-iniciativa-normativa-en-el-procedimiento-legislativo-europeo-a-la-luz-del-tratado-de-lisboa/?edicion=3.10

Vecchio, F. (2011). El procedimiento de Codecisión y el principio de subsidiariedad: ¿Un "cortocircuito" democrático? História: Debates e Tendências, 11 (1), 11-21. Hemendik eskuratua http://seer.upf.br/ index.php/rhdt/article/view/2484 